\title{
Involvement of Lipids in Dimethoate-Induced Inhibition of Testosterone Biosynthesis in Rat Interstitial Cells
}

\author{
Mariana Astiz · Graciela E. Hurtado de Catalfo • \\ María J. T. de Alaniz · Carlos Alberto Marra
}

Received: 25 November 2008/ Accepted: 13 May 2009/Published online: 5 July 2009

(C) AOCS 2009

\begin{abstract}
The mechanism involved in the inhibition of testosterone (Te) biosynthesis after a sub-chronic exposure to low doses of dimethoate (D) was studied in rat interstitial cells (IC). Expression of COX-2 in IC isolated from D-treated rats increased by $44 \%$ over $\mathrm{C}$ data, while transcription of StAR decreased by approx. 50\% and the expression of this protein was diminished by approximately $40 \%$. $\mathrm{PGE}_{2}$ and $\mathrm{PGF}_{2 \alpha}$ were increased by 61 and $78 \%$, respectively. Te concentration decreased by $49 \%$ in IC homogenates. Concomitantly, plasma concentration of $\mathrm{LH}$ and FSH both increased. Araquidonate (ARA) and $\mathrm{C}_{22}$ fatty acyl chains in phospholipids from IC mitochondrial fraction decreased by approx. 30\% after D treatment. Protein carbonyls, lipoperoxides and nitrite content increased while $\alpha$-tocopherol and the antioxidant capacity of the soluble cellular fraction decreased significantly. Stimulation with h-CG $10 \mathrm{nM}$ overnight failed to overcome the inhibition caused by $\mathrm{D}$ on both Te biosynthesis and $3 \beta$ - and $17 \beta$-hydroxysteroid dehydrogenases. Decreased Te biosynthesis may be attributed to (1) inhibition of StAR protein activity due to the stimulation of COX-2 and the overproduction of $\mathrm{PGF}_{2 \alpha}$, (2) decreased stimulatory effect of ARA on StAR with a subsequent reduction in the availability of $\mathrm{CHO}$ for the androgenic pathway, and/or (3) indirect inhibition of steroidogenic enzymes by a lower transcriptional rate caused by elevated
\end{abstract}

M. Astiz - G. E. Hurtado de Catalfo - M.

J. T. de Alaniz - C. A. Marra ( $\square)$

Instituto de Investigaciones Bioquímicas de La Plata

(INIBIOLP), CCT La Plata, CONICET-UNLP, Cátedra de

Bioquímica y Biología Molecular, Facultad de Ciencias

Médicas, Universidad Nacional de La Plata, Calles 60 y 120,

1900 La Plata, Argentina

e-mail: camarra@atlas.med.unlp.edu.ar;

contactocarlos@hotmail.com
PGF $_{2 \alpha}$. Rofecoxib administration prevents the deleterious effect(s) exerted by D.

Keywords Arachidonic acid - COX-2 - Dimethoate . Oxidative stress $\cdot$ Prostaglandins $\cdot$ Rat interstitial cells . StAR $\cdot$ h-CG $\cdot$ Rofecoxib $\cdot$ TROLOX

$\begin{array}{ll}\text { Abbreviations } \\ \text { C } & \text { Control group } \\ \text { CM } & \text { Cytoplasmic membrane } \\ \text { D } & \text { Dimethoate } \\ \text { FSH } & \text { Follicle-stimulating hormone } \\ \text { LH } & \text { Luteinizing hormone } \\ \text { LPO } & \text { Lipid peroxidation } \\ \text { MDA } & \text { Malonedialdehyde } \\ \text { N } & \text { Nucleus } \\ \text { OS } & \text { Oxidative stress } \\ \text { RNS } & \text { Reactive nitrogen species } \\ \text { PS } & \text { Protein synthesis } \\ \text { R } & \text { Rofecoxib } \\ \text { ROS } & \text { Reactive oxygenated species } \\ \text { StAR } & \text { Steroidogenic acute regulatory protein } \\ \text { T } & \text { TROLOX } \\ \text { TBARS } & \text { Thiobarbituric acid-reactive substances } \\ \text { Te } & \text { Testosterone }\end{array}$

\section{Introduction}

The growing amount of experimental evidence documenting endocrine dysfunction in male wildlife has led to the hypothesis that environmental contaminants adversely affect testosterone production and caused deleterious 
effects on the male reproductive system [1]. In an interesting work, Carlsen et al. [2] reported that a significant worldwide decline in semen quality has occurred over the past 50 years. Retrospective studies performed in sperm banks from Paris [3] and London [4] have supported this conclusion. The hypothesis of environmental pollution as a causative factor is casually related to higher declines in sperm quality observed in developed countries characterized by important agrotechnical activities [5, 6]. Other authors reported that environmental chemicals can mimic estrogen action and also disrupt androgen signaling pathways [6]. Moreover, alterations were also observed not only in reproductive performance, but also in the incidence of cryptorchidism and testicular cancer [7]. Many contaminants demonstrated antiandrogenic activity both in whole animals and in receptor binding-in vitro assays [1]. Important evidence for this mechanism of action was obtained with the herbicide Linuron. This chemical agent binds to the androgen receptor with an affinity similar to that of flutamide, which is a potent antiandrogenic drug. As a result, feedback control to the pituitary is interrupted and serum LH and estrogen concentrations increase significantly. The ultimate outcome of Linuron exposure is Leydig cell cancer due to over-stimulation of steroidogenesis [8]. Several pesticides and their metabolites have similar effects [6,9]. Currently, the levels of environmental exposure to these substances and their derivatives are completely unknown. Thus, predictions about alterations in male reproductive function or fertility cannot be made $[6,10]$. This fact has generated considerable public and scientific concern about the relationship existing between environmental contaminants and alterations to the male reproductive system [11].

Some of the most used agrochemicals have been shown to disturb pro-oxidant/anti-oxidant balance in testicular cells and consequently decrease the androgen production [6]. Free radical generation in response to toxicants [12] plays different and complex roles in the Leydig cell physiology [6]. For example, high levels of corticosterone produced during oxidative stress may bring about, in part, the decline in testosterone biosynthesis since this steroid is able to induce Leydig cell apoptosis [13]. In addition, testosterone production is profoundly affected by the prostaglandin $\mathrm{F}_{2 \alpha}\left(\mathrm{PGF}_{2 \alpha}\right)$ level. The inducible enzyme cyclooxygenase-2 (COX-2) is responsible for the biosynthesis of $\mathrm{PGF}_{2 \alpha}$ from its precursor arachidonic acid (ARA). $\mathrm{PGF}_{2 \alpha}$ not only inhibits progesterone production but also activates its own biosynthetic pathway by induction of COX-2 via protein kinase $\mathrm{C}$ in an autoamplification cascade [14]. In this scenario it is possible to assume that pesticides induce oxidative stress (OS) and disturb the conversion of ARA into $\mathrm{PGF}_{2 \alpha}$ via COX-2. In addition, other laboratories have demonstrated that COX-2 and
$\mathrm{PGF}_{2 \alpha}$ are both inhibitors of Leydig cell steroidogenesis $[14,15]$.

In Leydig cells, cholesterol is converted to testosterone through various steps catalyzed by different enzymes [16]. The delivery of free cholesterol to the inner mitochondrial membrane is the true rate-limiting step of steroidogenesis and it is mediated mainly by the steroidogenic acute-regulatory protein (StAR) $[16,17]$. The biological activity of this protein depends on many factors such as ARA, PGF levels, COX-2 activity, and free radical production in a complex interrelationship not fully understood yet $[14,15$, 18-20]. StAR is also sensitive to various pesticides as demonstrated by Walsh et al. [21].

Some organophosphorus compounds are known to impair fertility, suppress libido, cause testicular degeneration, and a deterioration in semen quality [22]. Dimethoate (D; 2-dimethoxyphosphonylthio- $N$-methylacetamine) is an organophosphorus pesticide extensively used as a systemic insecticide and acaricide which proved to be neurotoxic [22] and to disturb StAR gene expression [21]. Toxicity of $\mathrm{D}$ on testicular Leydig cell function is still unexplored. Therefore, in the present study we aimed to investigate the action of a sub-chronic exposure of Wistar rats to low doses of D on Leydig cell steroidogenesis, free radical production, and StAR and COX-2 expression. The testis is the major site for testosterone production. It plays a crucial role in the development of secondary sexual characteristics and initiation, as well as regulation of spermatogenesis. Thus, reduction in testosterone production due to exposure to environmental toxicants (such as D) has the potential to adversely affect normal sexual development in humans.

\section{Experimental Procedure}

\section{Chemicals}

All chemicals used were of reagent grade and obtained from Sigma Chem. Co. (CA, USA, or Buenos Aires, Argentina) or Merck Laboratories (Darmstadt, Germany). Organic solvents were from Carlo Erba (Milano, Italy). $\alpha$-Tocopheryl-diacetate $\left(\right.$ TROLOX $^{\circledR}, 98 \%$ pure) and rofecoxib (99\% pure) were from Saporitti S.A., Buenos Aires, Argentina. Other chemicals employed were purchased from local commercial sources and they were of analytical grade. Dimethoate (2-dimethoxyphosphonylthio$\mathrm{N}$-methylacetamine) was obtained as a gift from INTA (Castelar, Argentina). Hormone measurements [luteinizing (LH), follicle-stimulating (FSH), total and free testosterone] were performed using commercial kits (KP7CT, $\mathrm{KP} 6 \mathrm{CT}$, KS24CT, and $\mathrm{KS} 33 \mathrm{CTN}$, respectively) from Radim (Radim SpA, Pomezia, Italy). 
Animals and Treatments

Male Wistar rats weighing $190 \pm 20 \mathrm{~g}$ with specific-pathogen free-certified status were used. Upon arrival, the rats were allowed to acclimatize for a week before starting the experiment. Rats were maintained under controlled conditions of temperature $\left(25 \pm 2{ }^{\circ} \mathrm{C}\right)$, and a normal photoperiod of $12 \mathrm{~h}$ dark and $12 \mathrm{~h}$ light. They were fed with standard Purina chow from Ganave S.A. (Santa Fe, Argentina) and water ad libitum. Clinical examination together with body weight evaluation was performed every week during the experiment. Animals were randomly divided into two groups of six rats each, assigned as control rats $(C)$ injected i.p. with polyethylene-glycol 400 (PEG-400), or D-treated rats injected with $15 \mathrm{mg} \mathrm{D} / \mathrm{kg}$ body weight dissolved in PEG-400. All animals were injected three times a week for 5 weeks. The dose used was in accordance with previous reports [23-26]. This model was chosen for simulation of a sub-chronic exposition to low doses of pesticide incorporated from the living environment [27]. Other experiment was designed to study the effect of the antioxidant $\alpha$-tocopheryl diacetate (TROLOX ${ }^{\circledR}$ ) and the COX inhibitor rofecoxib administered alone or in combination with dimethoate. In this experimental protocol TROLOX ${ }^{\circledR}(\mathrm{T})$ and rofecoxib (R) were dissolved in PBS with PEG-400 and administered i.p. to groups of 4 rats each at a doses of 12.5 and $5.0 \mathrm{mg} / \mathrm{kg}$ body weight, respectively. Two groups of rats received TROLOX ${ }^{\circledR}(\mathrm{CT})$ or rofecoxib $(\mathrm{CR})$, other two groups were simultaneously injected with D and T (DT) or D and R (DR). Finally, other groups of animals were injected with the vehicle alone $(C)$, dimethoate alone (D), or a combination of the three drugs (DTR). Animal maintenance and handling were in accordance with the NIH guide for the care and use of laboratory animals [28]. All procedures were approved by the local Laboratory Animal Bioethics Committee, Facultad de Ciencias Médicas, UNLP, Argentina.

\section{Sample Collection}

At the end of the treatment, the animals were decapitated. Blood was collected using heparin $(10 \mathrm{UI} / \mathrm{mL})$ as anticoagulant in graduated ice-cold polypropylene tubes. Plasma samples were immediately prepared by centrifugation $(4,000 \times g, 10 \mathrm{~min})$ and then stored at $-80{ }^{\circ} \mathrm{C}$ until analyzed. Testes were rapidly excised, washed, weighed, and homogenized in ice-cold phosphate buffer $100 \mathrm{mM}$ with $6 \mathrm{mM}$ of EDTA pH 7.40 (3 $\mathrm{ml}$ of buffer to $1 \mathrm{~g}$ of tissue). Homogenates were stored at $-80{ }^{\circ} \mathrm{C}$ until assayed.

\section{Analytical Methods}

Various biomarkers of oxidative stress and cell damage were measured in plasma and testicular interstitial cells.
Lipid peroxidation was assayed as authentic lipoperoxides (ROOHs) by the FOX assay [29]. ROOHs were expressed as nmol malondialdehyde (MDA)/mg protein. The sum of nitrates and nitrites $\left(\left[\mathrm{NO}_{x}\right]\right)$ was measured as the main endmetabolite products of nitric oxide (NO) and peroxynitrite anion $\left(\mathrm{ONOO}^{-}\right)$by the method of Miranda et al. [30]. Results were expressed as nmol of nitrites/mg protein. Protein carbonyls (nmol/mg of protein) were measured using the method of Reznick and Packer [31] as a biomarker of oxidative damage to proteins. We also measured parameters of the antioxidant defense system. The FRAP (ferric reducing ability of plasma) assay was determined by the method of Benzie and Strain [32] and the results were expressed as $\mu \mathrm{M}$ of equivalent TROLOX ${ }^{\circledR}$ or $\alpha$-tocopheryl acetate. Vitamin E ( $\alpha$-tocopherol) was measured after extraction by the method of Buttriss and Diplock [33] using the HPLC technique of Bagnati et al. [34] which can detect and quantify both $\alpha$ - and $\gamma$-tocopherols. Total glutathione (GSH) was measured by the method of Anderson and Meister [35] and expressed as $\mu \mathrm{mol} / \mathrm{mg}$ of protein. Protein contents were determined according to the method of Bradford [36].

\section{Cell Culture and Treatment}

Technical procedure for Leydig cell isolation was described in detail in a previous report [37]. Briefly, Leydig cells were removed from the interstitial space of testicular tissue by mechanical shaking with collagenase (Sigma Chem. Co., type IV) in a metabolic incubator, at $34{ }^{\circ} \mathrm{C}$, according to Suescon et al. [38]. Cells were suspended in Krebs Ringer bicarbonate glucose (KRBG) solution ( $\mathrm{pH} 7.4)$, examined for viability (90\%) by trypan blue exclusion [39], and counted in a hemocytometer to adjust cell concentration. Aliquots of cell suspensions were subjected to protein determination by the micromethod of Bradford [36]. Preparations of interstitial cells comprised a high percentage of Leydig cells. The homogeneity of cell preparations was assessed by means of the observation of smears fixed in acetone and stained with $\mathrm{H} \& \mathrm{E}$. Interstitial cell preparations consisted of Leydig cells (79\%) and $21 \%$ of spermatids, spermatocytes and small cytoplasmic fragments.

\section{Functional Assay}

The functional response of cultured interstitial cells was assayed by stimulation with chorionic gonadotrophin (h-CG, Ovusyn ${ }^{\circledR}$ from Syntex S.A., Buenos Aires, Argentina) $10 \mathrm{nM}$ for $12 \mathrm{~h}$. Cells were detached from the surface culture using mechanical harvesting, transferred to graduated polypropylene ice-cold tubes, and pelleted at $600 \times g$ for $10 \mathrm{~min}$. The pellet was washed twice with sonication buffer (65 mM Tris- $\mathrm{HCl}, \mathrm{pH} 7.0$, containing 10\% sucrose) 
and resuspended in the same medium. Cellular homogenates were prepared by sonication (three 30 -s bursts at medium power in a Heat Systems Ultrasonic sonicator model W-220F from Plainview, NY). Crude extracts were centrifuged at $2,000 \times g$ for $15 \mathrm{~min}$ and the supernatants were used for hormone measurements.

\section{Immunoblotting}

Cells were homogenized by sonication as described above in Tris/ $\mathrm{HCl} /$ sucrose buffer with a $1 \%$ antiprotease cocktail (Sigma Chem. Co, Bs. As., Argentina), and 2\% SDS. After heating the samples $(20 \mu \mathrm{g})$ at $95{ }^{\circ} \mathrm{C}$ for 3 min with $10 \%$ mercaptoethanol, aliquots were supplemented with $10 \%$ glycerol and $0.01 \%$ bromophenol blue and loaded on $12 \%$ SDS-PAGE mini-slabs (Mini protean II, Bio-Rad, Hercules, CA). Proteins were electrophoretically transferred overnight to PVDF membranes (Bio-Rad, Hercules, CA) using a transfer buffer containing $25 \mathrm{mM}$ Tris, $190 \mathrm{mM}$ glycine and $20 \%$ methanol. COX-2 protein levels were analyzed using a polyclonal antibody (Santa Cruz Biotechnology Inc., CA) while StAR protein was detected with a rabbit polyclonal antibody generated against amino acids $88-98$ of the $30 \mathrm{kDa}$ StAR protein prepared according to Clark et al. [17]. Blots were re-analyzed for $\alpha$-tubulin as the reference protein to control both loading and transfer processes. A polyclonal anti- $\alpha$-tubulin antibody from Oncogene (San Diego, CA) was used. Immunocomplexes were revealed with peroxidase-labeled secondary antibodies from Amersham Pharmacia Biotech AB (Upsala, Sweden). Semi-quantitation of Western blots was performed using the GeneGenius gel documentation system and GeneTools software from Syngene (Cambridge, UK). Results were normalized to $\alpha$-tubulin signal and expressed as "fold change" relative to the control (basal assay) which was assigned a value of 1 .

\section{Northern Blot Analysis}

To determine StAR mRNA expression, Leydig cells were collected by centrifugation at $2{ }^{\circ} \mathrm{C}(3,000 \times g$ for $10 \mathrm{~min})$ and washed twice with PBS. Total RNA purification was performed with TRIZol reagent following the manufacturer's instructions (Gibco-BRL, Grand Island, NY). Quantification and purities were checked by determination of the absorbance ratio at $260 / 280 \mathrm{~nm}$. Electrophoretic separation was performed in an agarose/formaldehyde gel with a linear gradient from 1 to 5\%. Hybond-P membranes (Amersham, GE Healthcare Ltd., Buckinghamshire, UK) were used for blotting the slabs. Membranes were stripped with a buffer containing $15 \mathrm{mM} \mathrm{NaCl}, 15 \mathrm{mM}$ Na citrate and $1 \%$ SDS (pH 7) for $40 \mathrm{~min}$ at $52{ }^{\circ} \mathrm{C}$. StAR mRNA on the membrane was probed with biotin-labeled mouse StAR
cDNA and detected using the North2South Chemiluminescent Nucleic Acid Hybridization and Detection Kit from Pierce (Pierce Biotechnology Inc. Rockford, IL) following the manufacturer's instructions.

$\mathrm{PGF}_{2 \alpha}$ and $\mathrm{PGE}_{2}$ Assays

For assessment of $\mathrm{PGF}_{2 \alpha}$ and $\mathrm{PGE}_{2}$ contents in the incubation media of interstitial cells, samples were centrifuged at $15,000 \times g$ for $20 \mathrm{~min}$ at $2{ }^{\circ} \mathrm{C}$. Supernatants were filtered though Millipore $0.2 \mu \mathrm{m}$ filters and concentrated by lyophilization in a Telstar Lyobeta freeze drying unit (Madrid, Spain). The residues were dissolved with $\mathrm{HCl} 2 \mathrm{~N}$ adjusting the $\mathrm{pH}$ to 3.5 . These solutions were injected into a 200-mg C 18 reverse phase Sep-columns (Peninsula Lab, Belmont, CA) and then eluted with ethyl acetate. The eluted fractions were evaporated to dryness under a nitrogen stream and reconstituted in buffers for enzymeimmuno assay (EIA) determinations. Prostaglandins were determined using commercially available kits Prostaglandin $\mathrm{F}_{2 \alpha}$ EIA Kit and Prostaglandin $\mathrm{E}_{2}$ Express EIA Kit from Cayman, Migliore Laclaustra S.R.L. (Buenos Aires, Argentina) with a minimum detection of 4 and $30 \mathrm{pg} / \mathrm{mL}$, respectively. Intra- and inter-assay coefficients of variation were in the range of $8-12 \%$ for both kits.

\section{Lipid Analysis}

Total lipids were extracted by the method of Folch et al. [40]. The phospholipid fraction was separated from the Folch extracts by the micro-column chromatography method described elsewhere [41] and quantified as phosphorus content [42] after mineralization of an aliquot from the silicic acid partition. GLC of the FAME (fatty acid methyl esters) was performed as indicated in one of our previous papers [43] except that in this case we used a capillary column mounted on a Hewlett Packard HP 6890 Series GC System Plus (Avondale, PA) equipped with a terminal computer integrator and data station. The FAMEs were identified by comparison of their relative retention times with authentic standards and mass distribution was calculated electronically by quantification of the peak areas. Eicosamonoenoic acid (20:1) was used as the internal standard. Cholesterol content was enzymatically measured according to Allain et al. [44] using a commercial kit from Wienner Lab. (Rosario, Argentina).

Steroidogenic Enzyme Activities

Appropriate aliquots of supernatants were employed to determine 3 - $\beta$-hydroxysteroid-dehydrogenase $(3 \beta \mathrm{HSD})$ and 17- $\beta$-hydroxysteroid-dehydrogenase (17 $\beta \mathrm{HSD}$ ) [EC 1.1.1.51] enzyme activities following the method of 
Marugesan et al. [45]. Sonicated interstitial cells were centrifuged $\left(10,000 \times \mathrm{g}, 15 \mathrm{~min}, 1-2^{\circ} \mathrm{C}\right)$. Supernatants were mixed with charcoal in order to remove the endogenous steroids and the samples were again centrifuged $\left(10,000 \times g 15 \mathrm{~min}, 2{ }^{\circ} \mathrm{C}\right)$. The reaction conditions were defined in preliminary experiments, in which the enzyme activities were tested by varying the incubation times and concentrations of substrates, protein, and cofactors. Assays were performed under initial velocity conditions in a reaction mixture ( $250 \mu \mathrm{L}$ final volume) containing $10 \mu \mathrm{M}$ of the steroid substrate $\left(\Delta^{4}\right.$-androstenedione or pregnenolone for $17 \beta \mathrm{HSD}$ and $3 \beta \mathrm{HSD}$, respectively), $1 \mathrm{mM}$ NADPH $(17 \beta \mathrm{HSD})$ or $0.2 \mathrm{mM} \mathrm{NAD}{ }^{+}(3 \beta \mathrm{HSD})$, and $0.1 \mathrm{M}$ phosphate buffer ( $\mathrm{pH}$ 7.4). Mixtures were incubated under air in a spectrophotometric cell holder thermostatized at $37{ }^{\circ} \mathrm{C}$. The reactions were started by the addition of the supernatant aliquots and OD changes of the nicotinamide cofactor(s) were measured. The incubation mixture deprived of substrate(s) was used as control.

\section{Statistical Analysis}

Results were analyzed by one way analysis of variance (ANOVA) followed by the Tukey multiple comparison test. Data were expressed as means \pm standard deviation (SD) of six independent determinations. They were considered different with respect to control data at the level of significance of $* P<0.05$ or $* * P<0.01$. In some of the Figures or Tables where multiple comparisons can be done we used different superscript letters to indicate statistical significances among results. Correlation and regression analyses and data plotting were automatically performed with the aid of Systat (version12.0 for Windows) from SPSS Science (Chicago, IL) or Sigma Scientific Graphing Software (version 8.0) from Sigma Chem. Co. (St. Louis, MO).

\section{Results}

Influence of Treatments on Growth Parameters

The influence of the treatments on feeding parameters is shown in Table 1. Dimethoate treatment did not influence significantly the water consumption (approximately $15 \mathrm{~mL} /$ day), the final body weights, the rate of body weight gain, or the food efficiency ratio. Similar conclusions were obtained for the other treatments assayed (R, T or combined administrations; data not shown). We did not found absolute and relative testicular weight changes. Pesticide exposure-alone or in combination with the other drugsdid not affect the animal behavior. Also, no visible signs of toxicity and/or cholinergic effects were observed during the entire experimental period.
Table 1 Main feeding parameters associated with experimental treatments

\begin{tabular}{|c|c|c|}
\hline \multirow[t]{2}{*}{ Parameters } & \multicolumn{2}{|l|}{ Treatments } \\
\hline & $\mathrm{C}$ & $\mathrm{D}$ \\
\hline Initial body weight (g) & $181.0 \pm 3.7$ & $174.0 \pm 7.3$ \\
\hline Final body weight (g) & $307.5 \pm 13.7$ & $288.8 \pm 20.9$ \\
\hline Body weight gain $(\mathrm{g})$ & $126.5 \pm 3.4$ & $114.8 \pm 5.5$ \\
\hline Rate of body weight gain (g/day) & $3.6 \pm 0.1$ & $3.3 \pm 0.2$ \\
\hline Food efficiency ratio ${ }^{a}$ & $9.5 \pm 0.2$ & $8.7 \pm 0.3$ \\
\hline Absolute testicular weight (g) & $2.8 \pm 0.1$ & $2.9 \pm 0.1$ \\
\hline Relative testicular weight $(\mathrm{mg} / \mathrm{g})^{\mathrm{b}}$ & $9.1 \pm 0.3$ & $10.0 \pm 0.4$ \\
\hline
\end{tabular}

Values represent the means $\pm \mathrm{SD}(n=8)$

$C$ control rats, $D$ dimethoate-treated rats

${ }^{\text {a }}$ Food efficiency ratio $=[$ body weight gain $(\mathrm{g}) /$ food intake $(\mathrm{g})] \times 10^{2}$

${ }^{\mathrm{b}}$ Relative testicular weight $=$ testis weight $(\mathrm{mg}) /$ body mass $(\mathrm{g})$

Testosterone Biosynthesis

Plasmas from dimethoate (D)-treated rats contained less free and bound testosterone compared to control animals (Table 2). In samples from dosed rats, a decrease of approximately $20 \%$ was observed in both parameters whereas the ratio free/bound testosterone was not modified. We observed a more significant decrease in testosterone levels (approximately 50\%) when sonicated interstitial cells were analyzed. Plasma estradiol concentration was decreased in D-treated rats by approximately $30 \%$, while LH and FSH were increased by 58 and $76 \%$, respectively (Table 2).

Table 2 Hormone levels in plasma and interstitial cellular homogenates from control (C) or dimethoate-treated (D) rats

\begin{tabular}{lrc}
\hline Determinations & \multicolumn{1}{l}{ C } & \multicolumn{1}{l}{$\mathrm{D}$} \\
\hline Plasma & & \\
Free testosterone $(\mathrm{nM})$ & $4.7 \pm 0.2$ & $3.9 \pm 0.1^{* *}$ \\
Bound testosterone $(\mathrm{nM})$ & $22.2 \pm 1.5$ & $17.1 \pm 3.0^{* *}$ \\
Free/bound testosterone $\times 10^{3}$ & $212 \pm 15$ & $228 \pm 12$ \\
Estradiol $(\mathrm{pg} / \mathrm{mL})$ & $15.1 \pm 0.6$ & $11.0 \pm 0.4^{* *}$ \\
LH (mU/mL) & $7.7 \pm 0.2$ & $12.2 \pm 0.6^{* *}$ \\
FSH (mU/mL) & $8.1 \pm 0.4$ & $14.3 \pm 0.8^{* *}$ \\
Cellular homogenates & & \\
Total testosterone (pmol/mg protein) & $27.9 \pm 1.3$ & $14.2 \pm 0.9^{* *}$ \\
\hline
\end{tabular}

Hormone levels were analyzed using RIA kits commercially available from Radim as indicated in the Experimental procedures. Data were expressed as the means \pm standard error of six independent determinations assayed in triplicate

Results significantly different to those of the corresponding control value are indicated with asterisks $(P<0.01)$ 


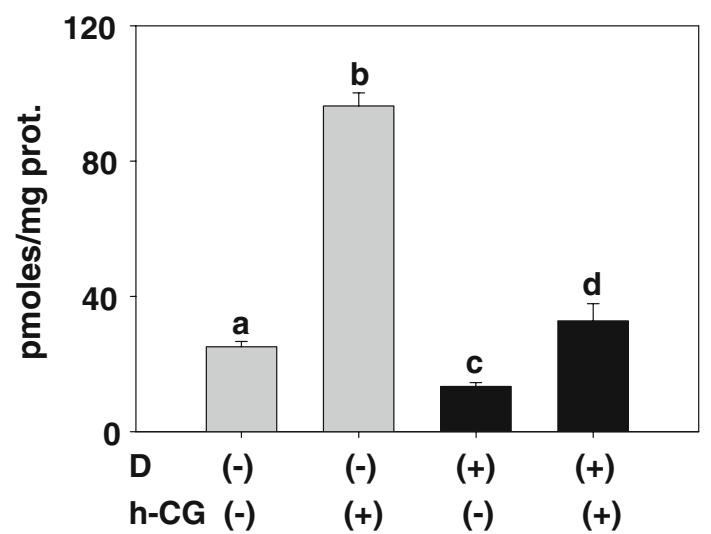

Fig. 1 Testosterone production of interstitial cells isolated from control (gray bars) or dimethoate (D)-treated (black bars) rats incubated in the presence or not of h-CG $10 \mathrm{nM}$ for $12 \mathrm{~h}$. Results were the means $\pm \mathrm{SD}$ of six independent determinations performed by RIA as indicated in the "Experimental procedure". Different superscript letters correspond to statistically significant differences at $P<0.01$

Interstitial cell cultures from $\mathrm{C}$ or $\mathrm{D}$ rats exhibited a very different behavior after $12-\mathrm{h}$ stimulation with $10 \mathrm{nM}$ human chorionic gonadotrophin (h-CG) (Fig. 1). Cells isolated from $\mathrm{C}$ rats released four times the basal testosterone production after overnight stimulation. In contrast, the cells isolated from D-treated rats exhibited significantly decreased basal levels and they only doubled the concentration of testosterone after the functional test with h-CG. Thus, we observed a 50\% reduction in androgen production in h-CG-stimulated cells from D rats (Fig. 1).

Direct measurement of the two key androgenic enzyme activities which regulate testosterone biosynthesis were performed in supernatants from interstitial cell sonicates after a h-CG stimulation assay (Fig. 2). Both enzymes activities, $3 \beta$-and $17 \beta$-hydroxysteroid dehydrogenases $(3 \beta \mathrm{HSD}$ and $17 \beta \mathrm{HSD}$, respectively) (Fig. $2 \mathrm{~A}, \mathrm{~B})$, were significantly lower $(40-50 \%)$ after dimethoate treatment. Neither of the two enzymes exhibited a significant change after h-CG stimulation independent of the previous treatment of the animals and cells (Fig. 2).

\section{Oxidative Stress Biomarkers}

A condition of oxidative stress (OS) was clearly established in D-treated rats. This condition was characterized by a general failure of the antioxidant defense enzymes, a lower level of $\alpha$-tocopherol and increased concentrations of oxidative damage biomarkers in plasma (data not shown). In interstitial cells of D-treated rats, a significantly higher level of ROOHs which are reliable biomarkers of lipid oxidative damage (Fig. 3A). Levels of protein carbonyls
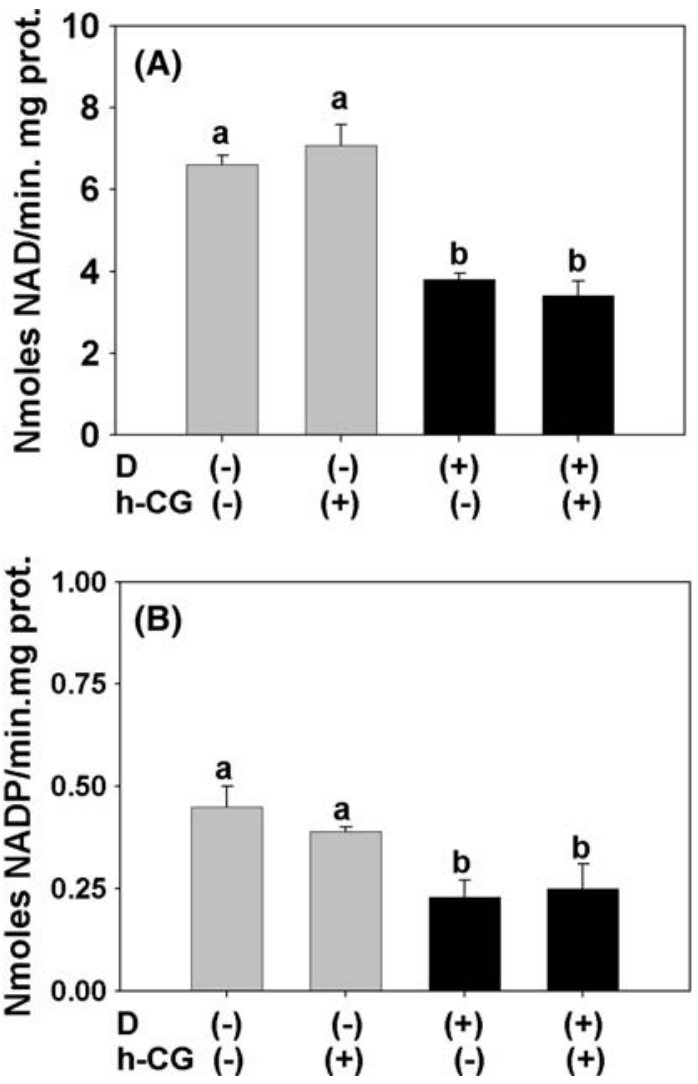

Fig. 2 Steroidogenic enzyme activities in interstitial cells prepared from control (gray bars) or dimethoate (D)-treated (black bars) rats previously incubated or not with h-CG $10 \mathrm{nM}$ for $12 \mathrm{~h}$. Enzyme activities (A $3 \beta \mathrm{HSD}$, B $17 \beta \mathrm{HSD}$ ) were expressed as nmol of NAD or $\mathrm{NADP} / \mathrm{min} \mathrm{mg}$ protein and correspond to the means of six independent assays performed in duplicates \pm SD. See "Experimental procedure" for details. Different superscript letters correspond to statistically significant differences at $P<0.01$

and $\left[\mathrm{NO}_{x}\right]$ (nitrates + nitrites), which reflects the oxidative damage to proteins and the stimulation of NOS activity, respectively, were both increased by the administration of the pesticide (Fig. 3A). After dimethoate treatment, the total glutathione concentration increased (Fig. 3A) while $\alpha$-tocopherol decreased (Fig. 3B). The FRAP assay was performed in sonicated interstitial cells from $\mathrm{C}$ and $\mathrm{D}$ rats as a biomarker of the total antioxidant ability. In cells from D-treated rats, FRAP was lower by approximately $30 \%$ compared with control animals (Fig. 3C).

\section{StAR and COX-2 Expression}

The level of StAR mRNAs was estimated by Northern blotting. A representative result is shown in Fig. 4A. Lanes 1 and 2 correspond to control interstitial cells while lanes 3 and 4 to cells isolated from D-treated rats. Chorionic gonadotrophin was added to the cultures analyzed in lanes 2 and 4. The same scheme was followed when the 

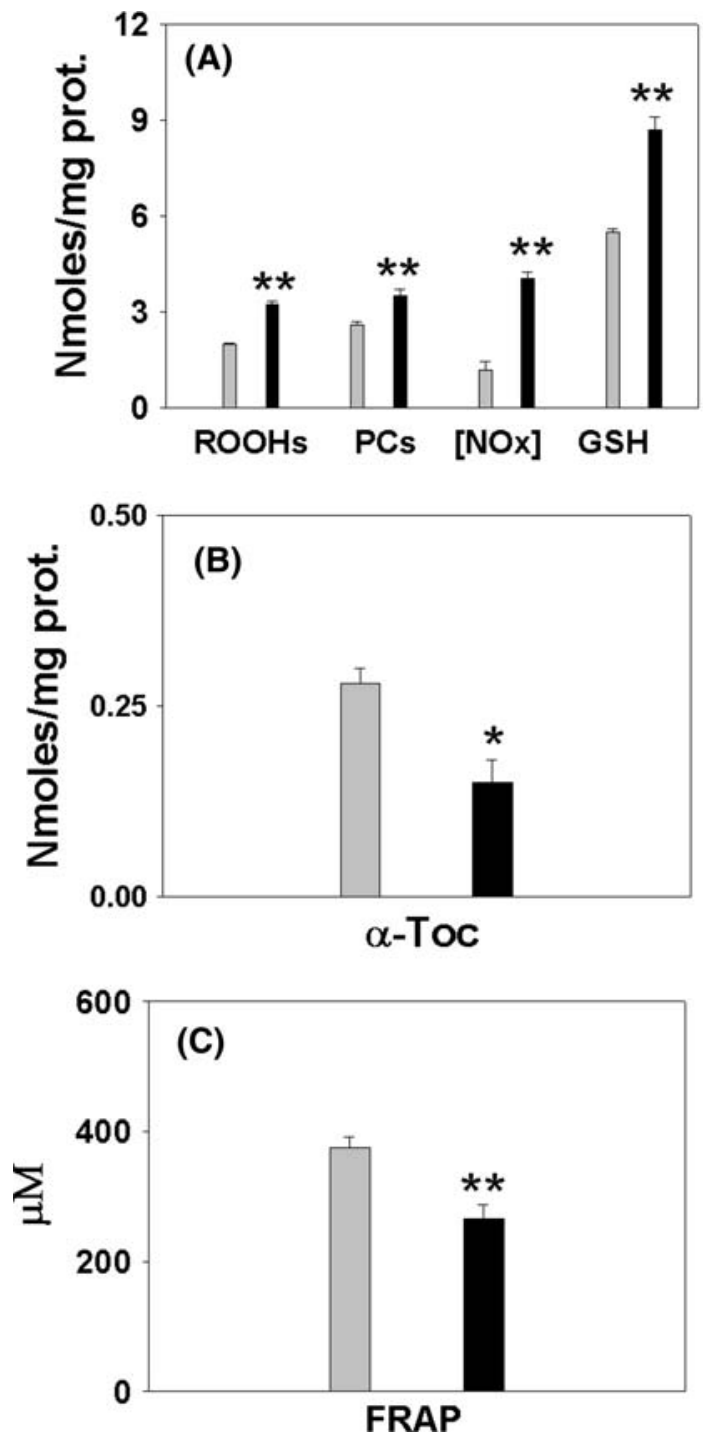

Fig. 3 Oxidative stress biomarkers measured in interstitial cells from control (gray bars) or dimethoate-treated (black bars) rats. A Data for authentic lipoperoxides (ROOHs), protein carbonyls (PCs), nitrates + nitrites $\left(\left[\mathrm{NO}_{x}\right]\right)$, and glutathione (GSH) levels. B $\alpha$-tocopherol concentration $(\alpha$-Toc), $\mathbf{C}$ the assay of the total antioxidant capacity (FRAP). Each value was expressed as the mean of six independent determinations \pm SD. Asterisks indicate significant difference with respect to control value $* P<0.05$ and $* * P<0.01$

expression of StAR or COX-2 proteins were tested by Western blotting (Fig. 4B). Relative quantification of the signals appeared in Fig. 5A and B. The h-CG stimulation provoked a significant increment of StAR at both transcriptional (Fig. 5A) and translational (Fig. 5B) levels. These increments were completely abolished by dimethoate treatment. Moreover, the pesticide evoked a reduction in the expression of StAR mRNAs, and also in its translation products (StAR protein). In contrast, dimethoate increased the biosynthesis of COX-2 protein at levels
A StAR mRNAs

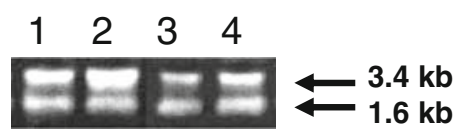

B Immunoblots

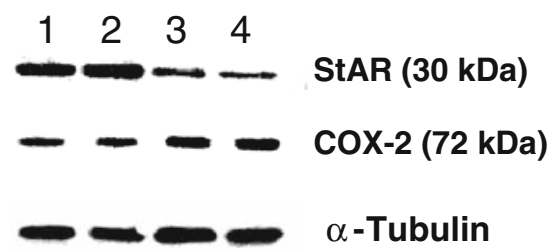

Fig. 4 Expression of mRNA StAR (A) and protein level for StAR and COX-2 (B) in interstitial cells. Lanes were: 1 control cells, 2 control stimulated with hCG $10 \mathrm{nM}$ for $12 \mathrm{~h}, 3$ D-treated cells, 4 D-treated cells stimulated with h-CG. Results are representative of six different incubations run in duplicate. See details in the "Experimental procedure" part

which were very similar to those observed in both h-CG stimulated and non-stimulated cells (Fig. 5C).

Arachidonate Metabolism and Cholesterol Level

The analysis of interstitial cell phospholipids demonstrated that the content of total inorganic phosphate per mg protein was unaffected by dimethoate treatment (data not shown). However, the pesticide significantly modified the fatty acyl composition of membrane phospholipids (Fig. 6). Saturated palmitic and stearic acids were increased while arachidonic, docosapenta-, and docosahexaenoic acids were diminished. Similar alterations were observed in neutral lipids (data not shown).

The total lipid extract from the mitochondrial fraction was also analyzed by the absolute content of cholesterol and arachidonic acid (Table 3) using a coupled enzymatic procedure with cholesterol oxidase and quantitative capillary gas-liquid chromatography, respectively. Clear correlations between the androgen production and the content of these lipids were observed (Fig. 7). Testosterone concentrations in whole cells were linearly and positively correlated with cholesterol content $\left(r^{2}=0.92\right)$ and arachidonate levels $\left(r^{2}=0.98\right)$ in mitochondrial fractions from interstitial cells.

Cycloxygenase-related metabolites of arachidonate were also studied in interstitial cells under basal or h-CG-stimulated conditions using EIA methods (Fig. 8). Prostaglandins $\mathrm{F}_{2 \alpha}$, and its precursor $\left(\mathrm{PGE}_{2}\right)$, were both significantly higher in rats treated with dimethoate. Stimulation with h-CG provoked in both types of cellular cultures (control or D-treated) a slight—but not significant-change in the concentration of the prostaglandins analyzed compared with the corresponding reference culture (Fig. 8). 

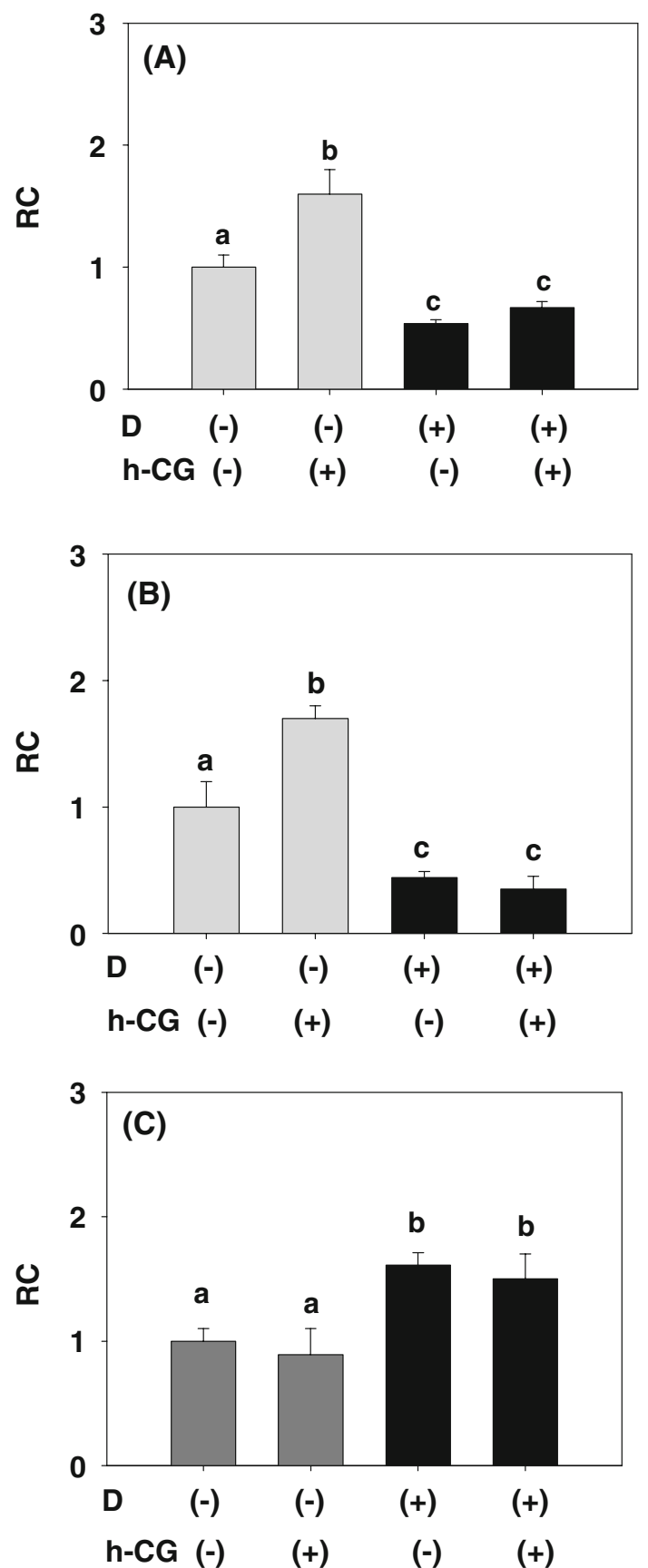

Fig. 5 Relative changes $(R C)$ of the expression of StAR mRNA (A), StAR protein $(\mathbf{B})$ or $\mathrm{COX}-2$ protein $(\mathbf{C})$, quantified by densitometry using the GeneGenius gel documentation system and GeneTools software from Syngene (Cambridge, UK). Results were normalized to $\alpha$-tubulin signal and expressed as "fold change" relative to the control (basal assay) which was assigned a value of 1 . Mean \pm SD. Different superscript letters correspond to statistically significant differences at $P<0.01$

\section{Antioxidant and COX-Inhibitor Effects}

The effects of the antioxidant TROLOX ${ }^{\circledR}$ or the COX inhibitor rofecoxib on various experimental parameters

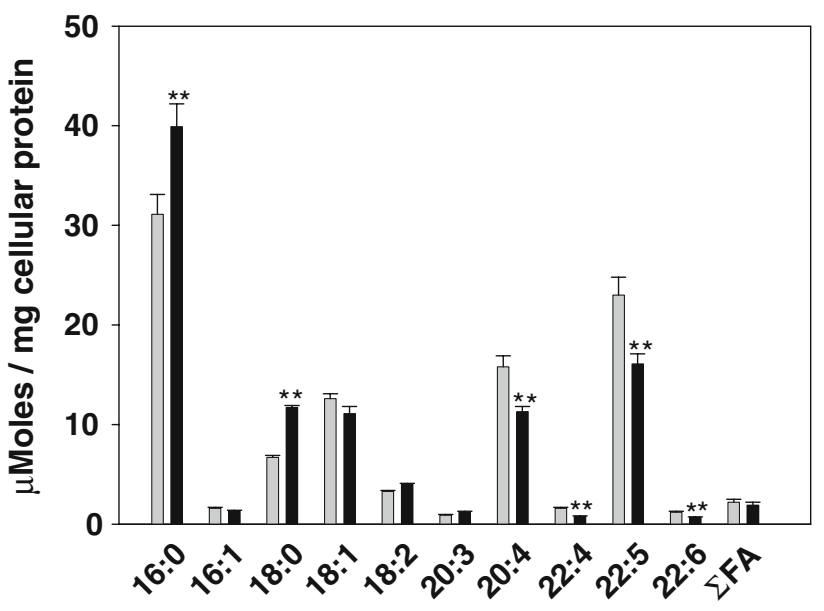

Fig. 6 Fatty acid composition of total phospholipids isolated from the mitochondrial fraction of interstitial cells prepared from control (gray bars) or dimethoate-treated (black bars) rats. Fatty acids were derivatized to methyl esters (FAMEs) and analyzed by capillary gasliquid chromatography under the conditions described in the "Experimental procedures". FAMEs were identified with authentic standards, quantified using eicosamonoenoic acid as internal standard and expressed as $\mu \mathrm{mol}$ of fatty acid per mg cellular protein (mean of six independent analyses $\pm \mathrm{SD}$ ). Double asterisks indicate significant difference with respect to control value at $P<0.01$. $\sum F$ A corresponds to the sum of other $\mathrm{C}_{22}$ and $\mathrm{C}_{24}$ fatty acids not identified in the chromatogram

measured on dimethoate-treated rats appear in Tables 4 (absolute values) and 5 (relative changes). Drugs were administered alone or in combination at dosages that effectively inhibited lipid peroxidation and COX-2 activity. TROLOX $^{\circledR}$ produced a strong decrease in the formation of D-induced ROOHs. However, the hormonal alterations evoked by dimethoate administration (essentially decreased testosterone biosynthesis and raised levels of the main gonadotrophin) were not normalized by simultaneous treatment with $\mathrm{D}$ and $\mathrm{T}$. The levels of ARA were not affected by the treatment with the antioxidant alone. In addition, the decreased level of ARA observed after D administration was not restored when the pesticide was associated with $\mathrm{T}$. Injection of $\mathrm{R}$ raised the level of ARA and at the same time significantly decreased the biosynthesis of $\mathrm{PGF}_{2 \alpha}$. Interestingly, testosterone concentration in both plasma and cellular homogenates was slightly (but significantly) higher while LH was lower under R treatment. Simultaneous administration of D and R normalized hormonal disturbances induced by $\mathrm{D}$; notwithstanding the production of ROOHs still persistent and markedly elevated (Table 4). The ARA and $\mathrm{PGF}_{2 \alpha}$ D-induced changes were completely reverted by the opposite and proportional effects displayed by $\mathrm{R}$ (Table 5 ). When the three drugs were administered in combination (DTR) all the parameters of those of control rats were indistinguishable. From these 
Table 3 Cholesterol and arachidonic acid levels of total lipids from the mitochondrial fraction isolated from interstitial cells from control or dimethoate-treated rats

\begin{tabular}{|c|c|c|c|c|}
\hline \multirow{2}{*}{$\begin{array}{l}\text { Cells } \\
\text { Treatment }\end{array}$} & \multicolumn{2}{|l|}{ Control } & \multicolumn{2}{|l|}{ Dimethoate } \\
\hline & None & $+\mathrm{h}-\mathrm{CG}$ & None & $+\mathrm{h}-\mathrm{CG}$ \\
\hline \multicolumn{5}{|l|}{ Lipids } \\
\hline Cholesterol (ng/ $\mu$ g protein) & $27.1 \pm 5.0^{\mathrm{a}}$ & $63.6 \pm 15.0^{\mathrm{b}}$ & $20.4 \pm 5.2^{\mathrm{c}}$ & $16.2 \pm 5.6^{\mathrm{c}}$ \\
\hline Arachidonic acid ( $\mu \mathrm{mol} / \mathrm{mg}$ protein $)$ & $36.2 \pm 6.6^{\mathrm{a}}$ & $57.3 \pm 3.2^{\mathrm{b}}$ & $25.5 \pm 5.0^{\mathrm{c}}$ & $31.2 \pm 4.3^{\mathrm{c}}$ \\
\hline
\end{tabular}

Total lipids were extracted from the mitochondrial fraction of the interstitial cells prepared from control or dimethoate-treated rats after incubation with or without h-CG $10 \mathrm{nM}$ for $12 \mathrm{~h}$. Total lipid fractions were fractioned into neutral and polar lipids using silicic acid partition, and then analyzed for cholesterol and arachidonic acid levels using enzymatic and chromatographic methods as described in "Experimental procedure". Results were expressed as the means of six independent determinations $\pm 1 \mathrm{SD}$ of the mean. Different superscript letters correspond to statistically significant differences at $P<0.01$
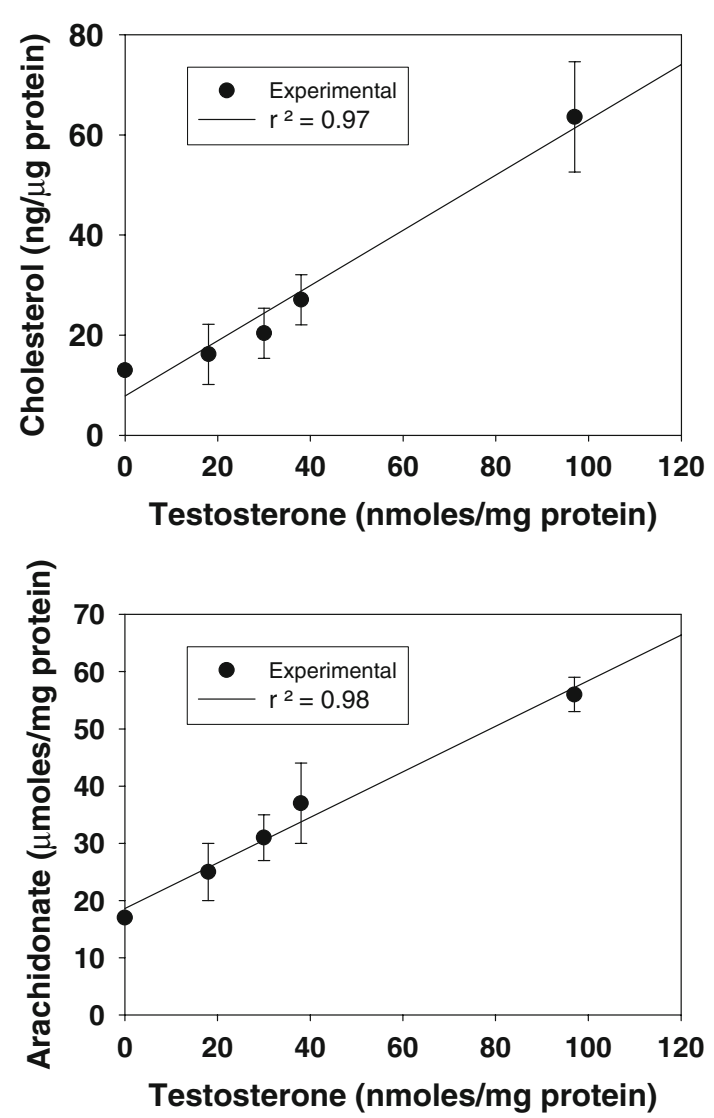

Fig. 7 Linear regressions and linear correlation coefficients $\left(r^{2}\right)$ for the relationship between cholesterol content of the mitochondrial fraction of interstitial cells and testosterone production (upper panel), or arachidonic acid level of the mitochondrial fraction of interstitial cells and testosterone production (lower panel). Data were obtained from basal or h-CG-stimulated cells from control or dimethoatetreated rats, and they were expressed as the means $\pm \mathrm{SD}$ of six independent measurements. Plots and $r^{2}$ were automatically generated by means of the statistical software described in the "Experimental procedure"

results, the main conclusion obtained is that there is an inverse proportionality between the changes induced by each drug assayed (D, T or R) that results in neutralization
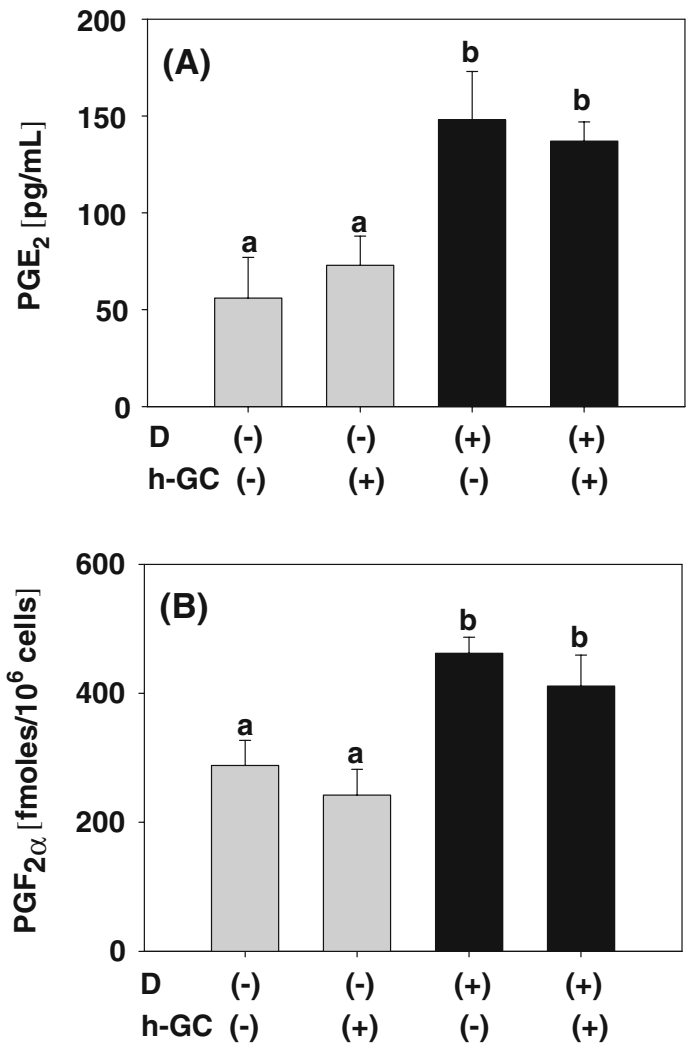

Fig. 8 Prostaglandins (PG) production from interstitial cell suspension prepared from control (gray bars) or dimethoate (D)-treated (black bars) rats incubated in presence or absence of h-CG $10 \mathrm{nM}$ for 12 h. $\mathrm{PGE}_{2}(\mathbf{A})$ or $\mathrm{PGF}_{2 \alpha}(\mathbf{B})$ were analyzed by EIA as described in the "Experimental procedure" section. Each datum is the mean $\pm \mathrm{SD}$ of six independent assays. Different superscript letters correspond to statistically significant differences at $P<0.01$

of the effects when they are combined. For example, the decrease in testosterone or the increased biosynthesis of $\mathrm{PGF}_{2 \alpha}$ produced by $\mathrm{D}$ were almost exactly compensated by simultaneous treatment with R. Also, it is evident that the generation of ROOHs does not parallel the changes of ARA concentrations suggesting that other fatty acids (in addition to ARA) are involved in the generation of free radicals. 
Table 4 Main experimental parameters determined after dimethoate (D), TROLOX ${ }^{\circledR}$ (T), or rofecoxib (R) treatments to rats

\begin{tabular}{|c|c|c|c|c|c|c|c|}
\hline \multirow[t]{2}{*}{ Analytical parameters } & \multicolumn{7}{|c|}{ Experimental groups } \\
\hline & $\mathrm{C}$ & $\mathrm{CT}$ & $\mathrm{CR}$ & $\mathrm{D}$ & DT & DR & DTR \\
\hline ARA $(\mu \mathrm{mol} / \mathrm{mg}$ cell protein $)$ & $15.5 \pm 0.7^{\mathrm{a}}$ & $16.2 \pm 0.8^{\mathrm{a}}$ & $19.4 \pm 0.9^{\mathrm{b}}$ & $9.8 \pm 0.1^{\mathrm{c}}$ & $10.1 \pm 0.5^{\mathrm{c}}$ & $15.3 \pm 0.6^{\mathrm{a}}$ & $14.9 \pm 0.8^{\mathrm{a}}$ \\
\hline PG $F_{2 \alpha}\left(\mathrm{fmol} / 10^{6}\right.$ cells $)$ & $294.7 \pm 11.9^{\mathrm{a}}$ & $319.3 \pm 6.5^{\mathrm{b}}$ & $95.3 \pm 8.5^{\mathrm{c}}$ & $454.4 \pm 9.1^{\mathrm{d}}$ & $486.5 \pm 12.3^{\mathrm{e}}$ & $301.9 \pm 15.8^{\mathrm{a}}$ & $301.0 \pm 9.6^{\mathrm{a}}$ \\
\hline ROOHs (nmol/mg protein) & $3.1 \pm 0.2^{\mathrm{a}}$ & $2.9 \pm 0.3^{\mathrm{a}}$ & $3.4 \pm 0.3^{\mathrm{a}}$ & $5.3 \pm 0.1^{\mathrm{b}}$ & $3.6 \pm 0.1^{\mathrm{c}}$ & $6.1 \pm 0.8^{\mathrm{b}}$ & $3.7 \pm 0.1^{\mathrm{a}}$ \\
\hline \multicolumn{8}{|l|}{ Hormones } \\
\hline Plasma testosterone (nM) & $5.0 \pm 0.2^{\mathrm{a}}$ & $4.9 \pm 0.1^{\mathrm{a}}$ & $5.9 \pm 0.2^{\mathrm{a}}$ & $3.8 \pm 0.1^{\mathrm{b}}$ & $4.0 \pm 0.1^{\mathrm{b}}$ & $4.8 \pm 0.1^{\mathrm{a}}$ & $5.1 \pm 0.2^{\mathrm{a}}$ \\
\hline $\begin{array}{l}\text { Cellular testosterone (pmol/ } \\
\text { mg protein) }\end{array}$ & $26.6 \pm 1.1^{\mathrm{a}}$ & $27.2 \pm 0.8^{\mathrm{a}}$ & $32.1 \pm 0.9^{\mathrm{a}}$ & $12.5 \pm 1.0^{\mathrm{b}}$ & $14.3 \pm 0.8^{\mathrm{a}}$ & $24.5 \pm 0.8^{\mathrm{a}}$ & $27.1 \pm 1.2^{\mathrm{a}}$ \\
\hline Plasma LH (mU/mL) & $6.9 \pm 0.2^{\mathrm{a}}$ & $7.0 \pm 0.1^{\mathrm{a}}$ & $5.8 \pm 0.2^{\mathrm{a}}$ & $15.1 \pm 0.7^{\mathrm{b}}$ & $13.5 \pm 0.5^{\mathrm{b}}$ & $7.3 \pm 0.1^{\mathrm{a}}$ & $6.8 \pm 0.2^{\mathrm{a}}$ \\
\hline
\end{tabular}

Data are expressed as the means \pm SD (four independent determinations assayed in duplicate). C, control group (injected with vehicle alone). $\mathrm{CT}, \mathrm{CR}$ and D were treated with TROLOX ${ }^{\circledR}$, rofecoxib or dimethoate, respectively. DT, DR, and DRT received combined administration of the drugs. Determinations were performed as described in the "Experimental procedure." Statistical comparisons (ANOVA plus Tukey's test) among experimental groups within a same row were indicated with different superscript letters

\section{Discussion}

The increasing use for organophosphorus insecticides has introduced a serious and novel hazard for humans and livestock animals [22]. Dimethoate is one of the most used agrochemicals around the world. Experimental evidence indicates that it impairs fertility, suppresses libido, causes testicular degeneration, and deteriorates semen quality [22]. Despite its residual action, this drug is extensively used in horticulture as a systemic insecticide and acaricide for treating gardens, vineyards, and field crops, and it is also applied externally for the control of fly larvae in cattle [22]. Previous studies from other laboratories demonstrated its adverse effects on semen performance [22] which were attributed to the presence of the dimethyl group in the moiety [46]. In our experiments, the testes were macroscopically examined to find visible evidence of toxic effect(s). We observed considerable changes in appearance, volume, and consistence of both testes of treated rats that suggest tissue edema. However, we did not observe significant changes in absolute and/or relative weights such as those reported by Farag et al. [47]. This probably could be due to differences in animal species, time/route of treatment, and the dose of dimethoate administered. Since the wet weights were conserved, this finding may indicate loss of testicular-specific structural tissue. This was strongly supported by the aspects of the testes previously decapsulated, and it is in agreement with findings of Sayim et al. [48, 49] that revealed a dimethoate-dose depended histopathological features of rat testes. Alterations reported were characterized by moderate to severe seminiferous tubule degeneration as sloughing, atrophy, germ cell degeneration, and partial arrest of spermatogenesis [48, 49].

Dimethoate was also involved in hormonal unbalance. Thomas et al. [50] suggested that this pesticide could block the uptake of steroid hormones at the interstitial cell receptor level. However, other research has previously proposed that dimethoate exerts a direct cytotoxic action not associated with alterations in LH, FSH, or other hormonal regulators implicated in androgen biosynthesis $[51,52]$. The present work demonstrate that low doses of dimethoate administered i.p. chronically are able to produce significant alterations in the levels of circulating gonadotrophin hormones which raise in response to a decrease testosterone production. The LH and FSH increases may have important consequences in the differentiation status of Leydig cells. In fact, previous studies demonstrated that this chronic stimulation is closely related to increased cancer degeneration [8]. The estradiol level, which reflects testosterone metabolism, is also significantly reduced after dimethoate treatment. Our results agree with an early investigation by Afifi et al. [22] who reported a decrease testosterone level of rats dosed orally with dimethoate for 2 months. We are unaware of any other studies that have examined in more detail the hormonal profile after dimethoate intoxication.

Oxidative stress is a well-known consequence of intoxication with environmental contaminants. This condition was repeatedly observed under metal overload [14, 53-56] or after intoxication with agrochemicals [20, 57, 58]. Some of the detrimental effects produced by pesticides in the male reproductive system were explained as a consequence of the exacerbated free radical production caused by these drugs [59]. It was proposed that most pesticides may act as pseudosubstrates for the generation of free radicals, which in turn, can damage P450 enzymes [6]. However, this suggestion is not accepted for all researchers since antioxidant supplementation failed to restore testosterone biosynthesis after intoxication by, for example, octylphenols [57]. Our results indicate that cultures of interstitial cells isolated from D-treated rats have a clear 
oxidative stress condition hallmarked by a general loss of the antioxidant capacity and elevation of biomarkers of OS damage. Interestingly, we observed an increased amount of the water-soluble antioxidant glutathione that could be ascribed to a compensatory mechanism of scavenging against the increased production of free radicals induced by dimethoate. This explanation is in agreement with previous experimental evidence indicating that $\gamma$-glutamyl-cysteinyl synthetase-which controls the biosynthesis of glutathione-is induced by a prolonged oxidative stress condition $[60,61]$. At the same time, the decreased level of $\alpha$-tocopherol could be the consequence of its increased rate of consumption within the lipophilic compartment of the interstitial cells. The loss of the lipid-soluble antioxidant capacity correlates well with the observed increase in the ROOHs production and the lower FRAP values. These findings led us to the idea that the testosterone level may be restored by antioxidant treatment. However, in agreement with the results reported by Murono et al. [57] (for the octylphenol inhibitory effect on testosterone biosynthesis) we did not find any positive effect caused by concomitant administration of $\mathrm{D}$ and $\mathrm{T}$ (Tables 4,5 ).

From this scenario, a first explanation for the decreased testosterone production could be proposed. Biosynthesis of this androgen in Leydig cells depends on the activities of two key enzymes ( $3 \beta$ HSD and $17 \beta$ HSD) which were inhibited in our experimental system in a clear correlation with the observed decrease in both the production of testosterone by Leydig cells and the plasma testosterone level. During the last years, free radical production has been linked to its possible role in reducing steroidogenesis [6265]. In addition, studies from Murugesan et al. [20, 45, 66] and Kostic et al. [67] suggested that androgenic dehydrogenases could be significantly inhibited by free radical overproduction. Thus, we think that-as judged by the normalization of ROOHs-OS induced by dimethoate treatment can be reverted by $\mathrm{T}$ administration; however, this fact may not contribute at least crucially to the loss of the androgenic capacity via $3 \beta$ - and $17 \beta$-dehydrogenase inhibition. These results support the assumption that $\mathrm{D}$ does not act as a pseudosubstrate that binds to the steroidbinding site of $\mathrm{P} 450$ enzymes (P450scc and P450c17) disrupting hydroxylation and leading to electron leakage and free radical production [57]. Also, it is unlikely that OS condition affects significantly the availability of NADPH that is required for the normal hydroxylation of steroids during P450 pathway for testosterone biosynthesis.

Another question concerning OS and steroidogenic activity can be discussed. It is well known that lipids can be destroyed by free radical attack. In particular, lipid peroxidation is now considered to be the main mechanism by which oxygen- or nitrogen-derived radicals can cause damage leading to impaired normal cellular function in testis [68]. Mammalian spermatozoa, being rich in polyunsaturated fatty acids (PUFAs) are more susceptible to oxidative damage resulting in sperm deterioration [6, 49]. Similar consequences can be assumed for Leydig cells which are also very rich in PUFAs [69]. Induction of OS by pesticides has been a focus of research over the last decade as a possible mechanism for infertility $[6,70]$. We observe that after intoxication with dimethoate a significant loss of PUFAs occurred in interstitial cells, specially arachidonic, docosapenta- and hexaenoic fatty acids (Fig. 6). $\mathrm{C}_{22}$ PUFAs are involved in spermatogenesis [71] while arachidonic acid (ARA) is directly linked to the androgenic activity of Leydig cells [16, 19]. Thus, it is possible that chronic OS may be an important mechanism for the arachidonate-dependent loss of steroidogenic ability since this fatty acid is essential for the biological activity of the steroidogenic acute regulatory protein (StAR) [72]. ARA level in Leydig cells is controlled by a hormone-regulated mechanism which involves an acyl-CoA synthetase (ACS4) and a mitochondrial acyl-CoA thioesterase (Acot2). Recent findings have demonstrated that, in steroidogenic cells, ARA release does not operate through the activation of the phospholipase $A_{2}$ pathway [73]. Experimental evidence supports the idea that ARA is released from the cholesteryl-ester pool and immediately converted into arachidonoyl-CoA by ACS4 [19]. This thioester binds to the acyl-CoA binding protein (DBI), which in turn, binds to the translocator protein (TSPO) located in the outer mitochondrial membrane. This would possibly facilitate a direct transference of arachidonoyl-CoA into the mitochondria [72]. In addition, ARA is transformed into lipoxygenated products which induce the transcription of StAR gene [72]. Thus, the conversion of cholesterol to testosterone is limited by the transport of cholesterol from the outer to the inner mitochondrial membrane. This event is controlled by StAR activity [21] and also by the ARA level [73, 74]. We have demonstrated that both ARA and cholesterol concentration are decreased in cells isolated from dimethoate-treated rats. Reduction of ARA, which in turn leads to the reduction of mitochondrial cholesterol content, could be produced by oxidative destruction of PUFAs due to D-induced OS, by an increased utilization via the COX-2 pathway, or both. Previous studies with rat mitochondrial fractions subjected to peroxidative conditions support the assumption that PUFA content can be effectively depleted by overproduction of free radicals [75]. In addition, recent studies from our laboratory indicated that plasmalogen subfraction is particularly enriched in ARA and very sensible to oxidative damage [76]. In addition, another pathway for ARA metabolism which is very active in interstitial cells, is the cyclooxygenase route that converts the precursor ARA into prostaglandins $G_{2}$, $\mathrm{H}_{2}, \mathrm{E}_{2}, \mathrm{D}_{2}$ and $\mathrm{F}_{2 \alpha}$ [77]. Cyclooxygenase isoenzymes types 
Table 5 Statistical comparisons and percent changes among experimental parameters determined after dimethoate (D), TROLOX ${ }^{\circledR}$ (T), or rofecoxib $(\mathrm{R})$ treatments to rats

\begin{tabular}{|c|c|c|c|c|c|c|}
\hline \multirow[t]{2}{*}{ Parameters } & \multicolumn{6}{|l|}{ Groups } \\
\hline & $\mathrm{CT}$ & $\mathrm{CR}$ & $\mathrm{D}$ & DT & DR & DTR \\
\hline ARA & $4.5 \pm 0.1$ n.s. & $25.2 \pm 1.2^{*}$ & $-36.7 \pm 1.6^{* *}$ & $-34.8 \pm 1.1^{* *}$ & $-1.3 \pm 0.1$ n.s. & $-3.9 \pm 0.2$ n.s. \\
\hline $\mathrm{PGF}_{2 \alpha}$ & $8.3 \pm 0.2$ n.s. & $-67.7 \pm 2.1 * *$ & $54.2 \pm 1.5^{* *}$ & $65.1 \pm 2.4^{* *}$ & $2.4 \pm 0.2$ n.s. & $2.1 \pm 0.3$ n.s. \\
\hline ROOHs & $-6.5 \pm 0.2$ n.s. & $9.7 \pm 0.3$ n.s. & $70.9 \pm 1.9 * *$ & $16.1 \pm 0.5 *$ & $96.7 \pm 2.1 * *$ & $19.4 \pm 0.4^{*}$ \\
\hline $\mathrm{Te}$ (plasma) & $-2.0 \pm 0.1$ n.s. & $18.0 \pm 0.4^{*}$ & $-24.0 \pm 0.6^{* *}$ & $-20.0 \pm 0.5^{*}$ & $-4.0 \pm 0.1$ n.s. & $2.0 \pm 0.1$ n.s. \\
\hline Te (cells) & $2.2 \pm 0.1$ n.s. & $17.1 \pm 0.3^{*}$ & $-53.0 \pm 2.1^{* *}$ & $-46.2 \pm 1.1^{* *}$ & $-7.9 \pm 0.3$ n.s. & $1.9 \pm 0.1$ n.s. \\
\hline LH (plasma) & $1.4 \pm 0.1$ n.s. & $-15.9 \pm 0.5^{*}$ & $118.8 \pm 4.6^{* *}$ & $95.6 \pm 3.1 * *$ & $5.8 \pm 0.2$ n.s. & $-1.4 \pm 0.1$ n.s. \\
\hline
\end{tabular}

Data were obtained from Table 4 and assayed by ANOVA plus Tukey's test. Percentage changes (expressed as means \pm SD) for a determined treatment were calculated as $[\mathrm{X}-\mathrm{C}] \times 100 / \mathrm{C}$, being $\mathrm{X}$ and $\mathrm{C}$ the tested and control paired data, respectively, within each group under comparison

$A R A$ arachidonic acid, $P G F_{2 \alpha}$ prostaglandin $\mathrm{F}_{2 \alpha}, R O O H s$ authentic hydroperoxides, Te testosterone

Statistical significances were indicated by asterisks $(* P<0.05$ and $* * P<0.01$ ), or with "n.s." (non-significant difference respect to the corresponding control group)

I (COX-1) and II (COX-2) are key enzymes that function coordinately and are controlled differentially by regulating the amount of ARA and lipid peroxides [78]. Previous studies from other laboratories suggested that COX-1 and COX-2 may not be important for male reproductive performance, at least in mice [77]. However, this early general view is being challenged by recent findings. COX-2 is overexpressed in human testis from men with impaired spermatogenesis, infertility, or degenerative disorders [79, 80]. Moreover, $\mathrm{PGF}_{2 \alpha}$ has been reported to significantly decrease StAR expression in porcine, rat, and human tissues [81-84]. In addition, Frungieri et al. [74] demonstrated that $\mathrm{PGF}_{2 \alpha}$ inhibition of h-CG-induced testosterone production in Leydig cells is accompanied by the downregulation of both StAR and $17 \beta \mathrm{HSD}$. Moreover, we observed elevated levels of trophic hormones in peripheral blood which failed to restore the androgenic capacity. This was in agreement with a previously demonstrated blockage of $\mathrm{PGF}_{2 \alpha}$ of the LH- or FSH-stimulatory pathway [85]. In vitro studies using MA-10 mouse Leydig cells further proved that inhibition of COX-2 activity significantly increased StAR protein expression and steroid production [86]. Our results strongly suggest that COX-2 is implicated in the inhibition of testosterone biosynthesis by dimethoate. We observed a significant increase in the level of COX-2 protein in cells isolated from dosed animals which correlated with the higher concentrations of both $\mathrm{PGE}_{2}$ and $\mathrm{PGF}_{2 \alpha}$. Concomitantly, StAR protein is diminished at both the gene expression and protein levels. These results also agree with those of Arakane et al. [87] who reported an inhibition of StAR gene expression by $\mathrm{PGF}_{2 \alpha}$. Concerning the role of COX-2 in testosterone production, we demonstrated that simultaneous administration of rofecoxib and dimethoate normalizes the hormonal levels to control values although the COX inhibitor was not able to modify the
ROOHs production (Tables 4, 5). From these results, we assume that the main target of dimethoate effect on steroidogenic route is COX-2 activity that leads to the overproduction of $\mathrm{PGE}_{2}$ and $\mathrm{F}_{2 \alpha}$ and subsequent inhibition of the StAR regulatory mechanism.

The status of androgenesis is usually tested (in vivo or in vitro) by the commonly accepted method of h-CG stimulation followed by the measurement of the testosterone production [12]. Interestingly, in our experimental system, the functional assay of stimulation with physiological concentration of h-CG does not normalize the changes induced by dimethoate, suggesting that the pesticide could act independently of gonadotrophin receptor-mediated events. This fact should be considered as another mechanism by which dimethoate can depress the pathway for androgen production. It remains to be explored whether this inhibitory response was initially triggered by overproduction of free radicals, and to what extent the overall effect can be attributed to the other(s) (synergistic) mechanism(s) involved. For example, previous studies by Diemer et al. [85] demonstrated that free radicals per se are able to inhibit StAR activity. However, results from Tables 4 and 5 suggest that OS may not have a crucial role in blocking StAR signal cascade directly or indirectly via gonadotrophin receptors. Whenever this crosstalk may (or not) occur, it seems quite possible that the ARA level was not (at least not entirely) depleted as a consequence of the oxidative stress condition since administration of $\mathrm{D}$ or $\mathrm{R}$ decrease and increase, respectively, the level of the acid in a clear correspondence with the COX-2 activity changes (Tables 4, 5). Thus, the increased production of $\mathrm{PGE}_{2}$ and $\mathrm{PGF}_{2 \alpha}$ should be produced-as observed in our experiments - through an important stimulation of the COX-2 activity which is inversely associated to the concentration of its substrate (ARA). As a consequence, StAR activity 


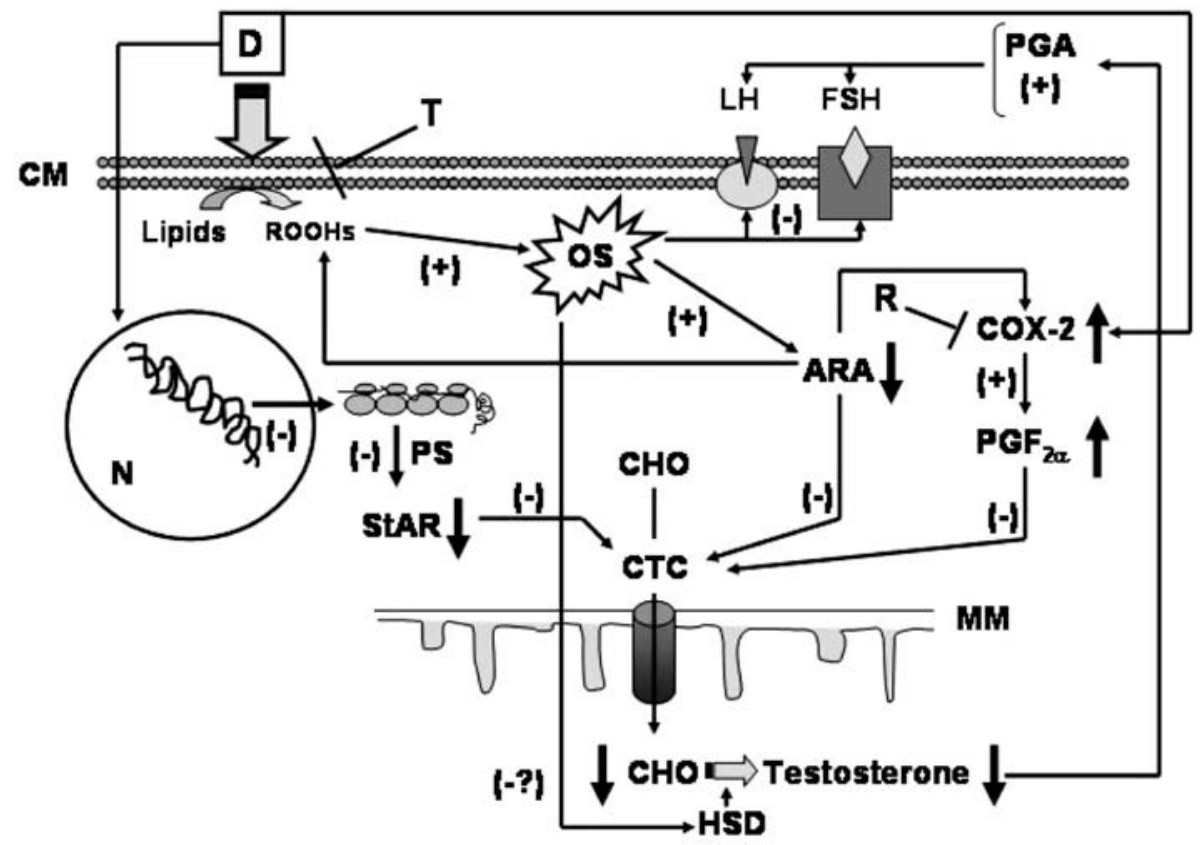

Fig. 9 Effects of chronic dimethoate intoxication on the steroidogenic status in rat testis. Dimethoate $(D)$ evokes a general failure in the antioxidant system and exacerbates the production of lipoperoxides $(R O O H s)$ which leads to an oxidative stress condition $(O S)$. This effect is effectively blockaded by administration of TROLOX ${ }^{\circledR}(T)$. The arachidonic acid (ARA) level decreases by conversion into peroxides principally due to exacerbated $\mathrm{COX}-2$ activity rather than the destruction by free radicals. This condition diminishes the efficiency of the cholesterol transport complex (CTC) located at the mitochondrial membrane $(M M)$. ARA is converted by the induced cyclooxygenase-2 $(C O X-2)$ into prostaglandin $\mathrm{F}_{2 \alpha}\left(P G F_{2 \alpha}\right)$ that inhibits the activity of the CTC. Rofecoxib $(R)$ blocks the activity

would be inhibited indirectly by either a decreased availability of ARA or an increased concentration of $\mathrm{PGF}_{2 \alpha}$. As reported previously, steroidogenesis is sensitive to small changes in StAR protein expression [21]. This question is important since StAR plays a key role in steroid production by gonads as well as in the steroidogenesis of adrenal glands. As a result, a disruption in StAR protein expression may impair more than just fertility. The biosynthesis of mineralo- and glucocorticoids may affect carbohydrate metabolism, immune system, and water balance. Such a general disturb may underline many of the toxic effects of environmental pollutants [21,88].

As a conclusion, we propose that dimethoate inhibits testosterone biosynthesis by multiple mechanisms of action (Fig. 9). Chronic intoxication, even at the low doses used in our experiments, provokes an oxidative stress which in turn raises the level of lipoperoxides and the activity of COX-2. As a consequence, a decreased rate of the StARstimulated cholesterol transport into the mitochondria was observed. Dimethoate treatment also blocks the activities of COX-2 and prevents the deleterious effect(s) of dimethoate $(D)$. Administration of $\mathrm{D}$ also reduces the expression of the gene which encodes the steroid acute regulatory protein $($ StAR) and its translation into active protein. The decreased production of StAR further inhibits the input of cholesterol $(\mathrm{CHO})$ by the mitochondria. All these effects act in concert to decrease the availability of $\mathrm{CHO}$ and its conversion into testosterone. Additional effects should be exerted on the activities of the $3 \beta$ - and $17 \beta$-hydroxysteroid dehydrogenases $(H S D)$, and on the signal transduction of $\mathrm{LH}$ and FSH which are increased by the pituitary-gonadal axis $(P G A)$ in response to the decreased production of testosterone. $C M$ cytoplasmic membrane, $N$ nucleus, $P S$ protein synthesis

of the hydroxysteroid dehydrogenases and impairs the LHor FSH-dependent signal for stimulation of androgen biosynthesis by a mechanism(s) that do not depend crucially on the ROOHs level. At the same time, increased COX-2 protein decreases StAR transcription and translation. The subsequent elevation of $\mathrm{PGF}_{2 \alpha}$ further inhibits StAR protein action decreasing both the availability of cholesterol and the rate of testosterone biosynthesis probably by inhibition of the $17 \beta \mathrm{HSD}$ mRNA transcription. The final biological effect suggests that the androgenesis status could provide a highly sensitive test for estimating the damage exerted by residual agrochemicals in chronically exposed populations. These conclusions should stimulate further research concerning the androgen functionality and the hormone level of men involuntarily exposed to dimethoate or others organophosphorus compounds. This fact also raised concern about the generality of the toxic action(s) of this kind of drugs on both the reproductive functions and the other metabolic pathways controlled by steroid hormones. 
Acknowledgments This study was supported by a grant from Consejo Nacional de Investigaciones Científicas y Técnicas (CONICET), Argentina. We would like to thank Mrs. Agustina Zardis de Cobeñas, Eva Illara de Bozzolo, and Norma Cristalli for their excellent technical assistance.

\section{References}

1. Cheek AO, McLachlan JA (1998) Environmental hormones and the male reproductive system. J Androl 19:5-10

2. Carlsen E, Giwercman A, Keiding N, Skakkeback NE (1992) Evidence for decreasing quality of semen during past 50 years. Biochem Med J 305:609-613

3. Auger J, Kunstmann JM, Czyglik F, Jouannet P (1995) Decline in semen quality among fertile men in Paris during the past 20 years. New Engl J Med 332:281-285

4. Ginsburg J, Okolo S, Prelevic G, Hardiman P (1994) Residence in the London area and sperm density. Lancet 343:230

5. Swan SH, Elkin EP, Fenster L (1997) Have sperm densities declined? A reanalysis of global trend data. Environ Health Perspect 105:1228-1232

6. Saradha B, Mathur PP (2006) Effect of environmental contaminants on male reproduction. Environ Toxicol Pharmacol 21:34-41

7. Swan SH, Kruse RL, Liu F, Barr DB, Drobnis EZ, Redmon JB, Wang C, Brazil C, Overstreet JW (2003) Semen quality in relation to biomarkers of pesticide exposure. Environ Health Perspect 111:1478-1484

8. Cook JC, Mullin LS, Frame SR, Biegel LB (1993) Investigation of a mechanism for leydig cell tumorigenesis by linuron in Rats. Toxicol Appl Pharmacol 119:195-204

9. Fry DM (1995) Reproductive effects in birds exposed to pesticides and industrial chemicals. Environ Health Perspect 103:165-171

10. Wong C, Kelce WR, Sar M, Wilson EM (1995) Androgen receptor antagonist versus agonist activities of the fungicide vinclozodin relative to hydroxyflutamide. J Biol Chem 270: 19998-20003

11. Irvine DS (2000) Male reproductive health: cause for concern? Andrologia 32:195-208

12. Andric NL, Andric SA, Zoric SN, Kostic TS, Stojilkovic SS, Kovacevic RZ (2003) Parallelism and dissociation in the actions of an aroclor 1260-based transformer fluid on testicular androgenesis and antioxidant enzymes. Toxicology 194:65-75

13. Wang GM, Ge RS, Latif SA, Morris DJ, Hardy MP (2002) Expression of $11 \beta$-hydroxylase in rat Leydig cells. Endocrinology 143:621-626

14. Gunnarsson D, Svensson M, Selstam G, Nordberg G (2004) Pronounced induction of testicular $\mathrm{PGF}_{2 \alpha}$ and suppression of testosterone by cadmium-prevention by zinc. Toxicology 200:49-58

15. Wang X, Dyson MT, Jo Y, Stocco DM (2003) Inhibition of cycloxygenase-2 activity enhances steroidogenesis and steroidogenic acute regulatory gene expression in MA-10 mouse Leydig cells. Endocrinology 144:3368-3375

16. Payne AH, Hales DB (2004) Overview of steroidogenic enzymes in the pathway from cholesterol to active steroid hormones. Endocr Rev 25:947-970

17. Clark BJ, Wells J, King SR, Stocco DM (1994) The purification, cloning, and expression of a novel luteinizing hormone-induced mitochondrial protein in MA-10 mouse Leydig tumor cells. Characterization of the steroidogenic acute regulatory protein (StAR). J Biol Chem 269:28314-28322
18. Chen H, Liu J, Luo L, Baig MU, Kim JM, Zirkin BR (2005) Vitamin E, aging and Leydig cell steroidogenesis. Exp Gerontol 40:728-736

19. Cano F, Poderoso C, Cornejo Maciel F, Castilla R, Maloberti P, Castillo F, Neuman I, Paz C, Podestá EJ (2006) Protein tyrosine phosphatases regulate arachidonic acid release, StAR induction and steroidogenesis acting on a hormone-dependent arachidocnic acid-preferring acyl-CoA synthetase. J Steroid Biochem Mol Biol 99:197-202

20. Murugesan P, Baladaneshi M, Balasubramanian K, Arunakaran J (2007) Effects of polychlorinated biphenyl (Aroclor 1254) on steroidogenesis and antioxidant system in cultured adult rat Leydig cells. J Endocrinol 192:325-338

21. Walsh LP, McCornick C, Martin C, Stocco DM (2000) Roundup inhibits steroidogenesis by disrupting steroidogenic acute regulatory (StAR) protein expression. Environ Health Perspect 108:769-776

22. Afifi NA, Ramadan A, Ae-Aziz MI, Saki EE (1991) Influence of dimethoate on testicular and epididymal organs, testosterona plasma level and their tissue residues in rats. Dtsch Tierärtl Wschr 98:419-423

23. Bagchi D, Bagchi M, Hassoun EA, Stohs SJ (1995) In vitro and in vivo generation of reactive oxygen species, DNA damage and lactate dehydrogenase leakage by selected pesticides. Toxicology 104:129-140

24. Bolognesi C, Morasso G (2000) Genotoxicity of pesticides: potential risk for consumers. Trends Food Sci Tech 11:182-187

25. John S, Kale M, Rathore N, Bhatnagar D (2001) Protective effect of vitamin $\mathrm{E}$ in dimethoate and malathion induced oxidative stress in rat erythrocytes. J Nutr Biochem 12:500-504

26. Sivapiriya V, Jayanthisakthisekaran Venkatraman S (2006) Effects of dimethoate (O, O-dimethyl $S$-methyl carbamoyl methyl phosphorodithioate) and ethanol in antioxidant status of liver and kidney of experimental mice. Pest Biochem Physiol 85:115-121

27. Cory-Slechta DA (2005) Studying toxicants as single chemicals: does this strategy adequately identify neurotoxic risk? Neurotoxicol 26:491-510

28. National Research Council (1985) Guide for the care and use of laboratory animals. Publication no. 85-23 (rev). National Institute of Health, Bethesda

29. Nourooz-Zadeh J, Tajaddini-Sarmandi J, McCarthy S, Betteridge DJ, Wolff SP (1995) Elevated levels of authentic plasma hydroperoxides in NIDDM. Diabetes 44:1054-1058

30. Miranda KM, Espey MG, Wink DA (2001) A rapid, simple spectrophotometric method for simultaneous detection of nitrate and nitrite. Nitric Oxide 5:62-71

31. Reznick AZ, Packer L (1994) Oxidative damage to proteins: spectrophotometric method for carbonyl assay. Methods Enzymol 233:357-363

32. Benzie IF, Strain JJ (1996) The ferric reducing ability of plasma (FRAP) as a measure of "antioxidant power": the FRAP assay. Anal Biochem 239:70-76

33. Buttriss JL, Diplock AT (1984) High-performance liquid chromatography methods for vitamin E in tissues. Methods Enzymol 105:131-138

34. Bagnati M, Bordone R, Perugini C, Cau C, Albano E, Bellomo G (1998) $\mathrm{Cu}(\mathrm{I})$ availability paradoxically antagonizes antioxidant consumption and lipid peroxidation during the initiation phase of copper-induced LDL oxidation. Biochem Biophys Res Commun 253:235-240

35. Anderson ME, Meister A (1984) Enzymic assay of GSSG plus GSH. Methods Enzymol 105:448-450

36. Bradford MM (1976) A rapid and sensitive method for the quantification of microgram quantities of protein utilizing the principle of protein-dye binding. Anal Biochem 72:248-254 
37. Hurtado de Catalfo GE, Mandon EC, de Gómez Dumm IN (1992) Arachidonic acid biosynthesis in non-stimulated and adrenocorticotropin-stimulated sertoli and Leydig cells. Lipids 27:593598

38. Suescun MO, González SI, Chiauzzi VA, Calandra RS (1985) Effects of induced hypoprolactinemia on testicular function during gonadal maturation in the rat. J Androl 6:77-82

39. Jauregui HO, Hayner NT, Driscoll JL, Williams-Holland R, Lipsky MH, Galletti PM (1981) Trypan blue dye uptake and lactate dehydrogenase in adult rat hepatocytes-freshly isolated cells, cell suspensions, and primary monolayer cultures. In Vitro 17:1100-1110

40. Folch J, Lees M, Sloane GH (1957) A simple method for the isolation and purification of total lipids from animal tissues. J Biol Chem 226:497-509

41. Hanahan DJ, Dittner JC, Warashina E (1957) A column chromatographic separation of classes of phospholipids. J Biol Chem 228:685-690

42. Chen PS, Toribara TY, Warner H (1956) Microdetermination of phosphorus. Anal Chem 33:1405-1406

43. Marra CA, de Alaniz MJT (1989) Influence of testosterone administration on the biosynthesis of unsaturated fatty acids in male and female rats. Lipids 24:1014-1019

44. Allain CC, Poon LS, Chan CS, Richmond W, Fu PC (1974) Enzymatic determination of total serum cholesterol. Clin Chem 20:470-475

45. Murugesan P, Kanagaraj P, Yuvaraj S, Balasubramanian K, Aruldhas MM, Arunakaran J (2005) The inhibitory effects of polychlorinated biphenyl Aroclor 1254 on Leydig cell LH receptors, steroidogenic enzymes and antioxidant enzymes in adult rats. Reprod Toxicol 20:117-126

46. Jackson H, Jones AR (1968) Antifertility action and metabolism of trimethyl-phosphate in rodents. Nature 220:591-592

47. Farag AT, El-Aswad AF, Shaaban NA (2007) Assesment of reproductive toxicity of orally administered technical dimethoate in male mice. Reprod Toxicol 23:232-238

48. Sayim F (2007) Histopathological effects of dimethoate on testes of rats. Bull Environ Contam Toxicol 78:479-484

49. Sayim F (2007) Dimethoate-induced biochemical and histopathological changes in the liver of rats. Exp Toxicol Pathol 59:237-243

50. Thomas JA, Donovan MD, Schein LG (1978) Biochemical bases for insecticide-induced changes in the male reproductive system. Toxicol Appl Pharmacol 45:291-295

51. Krause W (1977) Influence of DDT, DDVP, and malathion on FSH, LH and testosterone serum levels, and testosterone concentration in testes. Bull Environ Contam Toxicol 18:231-242

52. Krause W, Homola S (1974) Alterations of the seminiferous ephitelium and the Leydig cells of the mouse testis after application of dichlorvos. Bull Environ Contam Toxicol 11:429-433

53. Lucesoli F, Fraga CG (1999) Oxidative stress in testes of rats subjected to chronic iron intoxication and $\alpha$-tocopherol supplementation. Toxicology 132:179-186

54. Lucesoli F, Caligiuri M, Roberti MF, Perazzo JC, Fraga CG (1999) Dose-dependent increase of oxidative damage in the testes of rats subjected to acute iron overload. Arch Biochem Biophys $372: 37-43$

55. Guo CH, Huang CJ, Chen ST, Wang Hsu GS (2001) Serum and testicular testosterone and nitric oxide products in aluminiumtreated mice. Environ Toxicol Pharmacol 10:53-60

56. Guo CH, Lin CY, Yeh MS, Hsu GSW (2005) Aluminiuminduced suppression of testosterone through nitric oxide production in male mice. Environm Toxicol Pharmacol 19:33-40

57. Murono EP, Derk RC, de León JH (2000) Octylphenol inhibits testosterone biosynthesis by cultured precursor and immature Leydig cells from rat testes. Reprod Toxicol 14:275-288
58. Murono EP, Derk RC, de León JH (2001) Differential effects of octylphenol, 17 $\beta$-estradiol, endosulfan, or bisphenol $\mathrm{A}$ on the steroidogenic competence of cultured adult rat Leydig cells. Reprod Toxicol 15:551-560

59. Taylor CT (2001) Antioxidants and reactive oxygen species in human fertility. Environ Toxicol Pharmacol 10:189-198

60. Dringen R (2000) Metabolism and function of glutathione in brain. Prog Neurobiol 62:649-671

61. Dringen R (2005) Oxidative and antioxidative potential of brain microglial cells. Antioxid Redox Signal 7:1223-1233

62. Latchoumycandane C, Chitra KC, Mathur PP (2002) The effect of 2, 3, 7, 8-tetrachlorodibenzo- $p$-dioxin on mitochondrial and microsomal fractions of rat testis. Toxicology 171:127-135

63. Latchoumycandane C, Mathur PP (2002) Effect of methoxychlor on the antioxidant system in mitochondrial and microsome-rich fractions of rat testis. Toxicology 176:67-75

64. Chitra KC, Latchoumycanddane C, Mathur PP (2003) Induction of Oxidative Stress by Bisphenol A in the Epididymal Sperm of Rats. Toxicology 185:119-127

65. Chitra KC, Mathur PP (2004) Vitamin E prevents nonylphenolinduced oxidative stress in testis of Rats. Ind J Exp Biol 42:220-223

66. Murugesan P, Senthilkumar J, Balasubramanian K, Aruldhas MM, Arunakaran J (2005) Impact of polychlorinated biphenyl Aroclor 1254 on testicular antioxidant system in adult rats. Hum Exp Toxicol 24:61-66

67. Kostic TS, Andric SA, Maric D, Kovacevic RZ (2000) Inhibitory effects of stress-activated nitric oxide on antioxidant enzymes and testicular steroidogenesis. J Steroid Biochem Mol Biol 75:299-306

68. Cao L, Leers-Sucheta S, Azhar S (2004) Aging alters the functional expression of enzymatic and non-enymatic anti-oxidant defence systems in testicular rat Leydig cells. J Steroid Biochem Mol Biol 88:61-67

69. Coniglio JG (1994) Testicular lipids. Prog Lipid Res 33:387-401

70. Abdollabi M, Shadnia S, Nikfar S, Rezale A (2004) Pesticides and oxidative stress: a review. Med Sci Monit 10:RA141-RA147

71. Ayala S, Brenner RR, Dumm CG (1977) Effect of polyunsaturated fatty acids of the $\alpha$-linolenic series on the development of rat testicles. Lipids 12:1017-1024

72. Maloberti P, Maciel FC, Castillo AF, Castilla R, Duarte A, Toledo MF, Meuli F, Mele P, Paz C, Podestá EJ (2007) Enzymes involved in arachidonic acid release in adrenal and Leydig cells. Mol Cell Endocrinol 265(266):113-120

73. Wang XJ, Dyson MT, Mondillo C, Patrignani Z, Pignataro O, Stocco DM (2002) Interaction between arachidonic acid and cAMP signalling pathways enhances steroidogenesis and StAR gene expression in MA-10 Leydig tumor cells. Mol Cell Endocrinol 188:55-63

74. Catalá A (2007) The ability of melatonin to counteract lipid peroxidation in biological membranes. Curr Mol Med 7:638-649

75. Frungieri MB, González-Calvar SI, Parborell F, Albrecht M, Mayerhofer A, Calandra RS (2006) Cyclooxygenase-2 and Prostaglandin F2 $\alpha$ in Syriam Hamster Leydig cells: inhibitory role on luteinizin hormone/human chorionic-stimulated testosterone production. Endocrinology 147:4476-4485

76. Hurtado de Catalfo GE, de Alaniz MJT, Marra CA (2008) Dietary lipids modify redox homeostasis and steroidogenic status in rat testis. Nutrition 24:717-726

77. Smith WL, DeWitt DL, Garavito RM (2000) Cyclooxygenases: structural, cellular, and molecular biology. Annu Rev Biochem 69:145-182

78. Frungieri MB, Weidinger S, Meineke V, Köhn FM, Mayerhofer A (2002) Proliferative action of mast-cell tryptase is mediated by PAR2, COX-2, prostaglandins, and PPAR $\gamma$ : possible relevance to human fibrotic disorders. Proc Natl Acad USA 99:15072-15077 
79. Hase T, Yoshimura R, Matsuyama M, Kawahito Y, Wada S, Tsuchida K, Sano H, Nakatami T (2003) Cyclooxygenase-1 and -2 in human testicular tumours. Eur J Cancer 39:2043-2049

80. Chung PH, Sandhoff TW, McLean MP (1998) Hormone and prostaglandin $\mathrm{F} 2$ alpha regulation of messenger ribonucleic acid encoding steroidogenic acute regulatory protein in human corpora lutea. Endocrine 8:153-160

81. Fiedler EP, Plouffe LJr, Hales DB, Hales KH, Khan I (1999) Prostaglandin $\mathrm{F}(2 \mathrm{Alpha})$ induces a rapid decline in progesterone production and steroidogenic acute regulatory protein expression in isolated rat corpus luteum without altering messenger ribonucleic acid expression. Biol Reprod 61:643-650

82. Diaz FJ, Wiltbank MC (2005) Acquisition of luteolytic capacity involves differential regulation by prostaglandin F2Alpha of genes involved in progesterone biosynthesis in the porcine corpus luteum. Domest Anim Endocrinol 28:172-189

83. Shea-Eaton W, Sandhoff TW, Lopez D, Hales DB, McLean MP (2002) Transcriptional repression of the rat steroidogenic acute regulatory (StAR) protein gene by the AP-1 family member c-Fos. Mol Cell Endocrinol 188:161-170
84. Fuchs AR, Chantabraksri U (1981) Prostaglandin $F_{2 \alpha}$ regulation of LH-stimulated testosterone production in rat testis. Biol Reprod 25:492-501

85. Wang X, Dyson MT, Jo Y, Stocco DM (2008) Inhibition of cyclooxygenase-2 activity enhances steroidogenesis and steroidogenic acute regulatory gene expression in MA-10 mouse Leydig cells. Endocrinology 149:851-857

86. Arakane F, Kallen CB, Watari H, Foster JA, Sepuri NB, Pain D, Stayrook SE, Lewis M, Gerton GL, Strauss JF 3rd (1998) The mechanism of action of steroidogenic acute regulatory protein (StAR). StAR acts on the outside of mitochondria to stimulate steroidogenesis. J Biol Chem 273:16339-16345

87. Diemer T, Allen JA, Hales KH, Hales DB (2003) Reactive oxygen disrupts mitochondria in MA-10 tumor Leydig cells and inhibits steroidogenic acute regulatory (StAR) protein and steroidogenesis. Endocrinology 144:2882-2891

88. Reinhart AJ, Williams SC, Stocco DM (1999) Transcriptional regulation of the StAR gene. Mol Cell Endocrinol 151:161-169 